\title{
Sinorhizobium fredii USDA257 Releases a 22-kDa Outer Membrane Protein (Omp22) to the Extracellular Milieu When Grown in Calcium-Limiting Conditions
}

\author{
Won-Seok Kim, ${ }^{1}$ Jeong Sun-Hyung, ${ }^{2}$ Ro-Dong Park, ${ }^{3}$ Kil-Yong Kim, ${ }^{3}$ and Hari B. Krishnan ${ }^{1,2}$ \\ ${ }^{1}$ Plant Genetics Research Unit, Agricultural Research Service, United States Department of Agriculture, University of \\ Missouri, Columbia, MO 65211, U.S.A.; ${ }^{2}$ Department of Agronomy, University of Missouri, Columbia, MO 65211, U.S.A.; \\ ${ }^{3}$ Division of Applied Bioscience and Biotechnology, Institute of Agricultural Science and Technology, APSRC, Chonnam \\ National University, Kwangju 500-757, Korea
}

Submitted 18 February 2005. Accepted 31 March 2005.

Calcium, which regulates a wide variety of cellular functions, plays an important role in Rhizobium-legume interactions. We investigated the effect of calcium on surface appendages of Sinorhizobium fredii USDA257. Cold-field emission scanning electron microscopy observation of USDA257 grown in calcium-limiting conditions revealed cells with unusual shape and size. Transmission electron microscopy observation revealed intact flagella were present only when USDA257 cells were grown in calcium-sufficient conditions. Sodium dodecyl sulfate-polyacrylamide gel electrophoresis analysis of flagellar preparations from USDA257 cells grown in calcium-limiting conditions showed the presence of a 22-kDa protein that was absent from cells grown in calcium-sufficient conditions. We have cloned and determined the nucleotide sequence of the gene encoding the 22$\mathrm{kDa}$ protein. After successful expression in Escherichia coli, polyclonal antibodies were raised against the recombinant 22-kDa protein (Omp22). Subcellular fractionation analysis demonstrated that Omp22 was predominantly present in the extracellular fraction. Western blot analysis revealed the presence of immunologically related proteins from diverse rhizobia. Immunocytochemical localization of thin sections of USDA257 cells showed specific labeling of protein A-gold particles on protein inclusions found proximal to the cells. Accumulation of Omp22 was greatly reduced when USDA257 cells were grown in the presence of increasing calcium. Northern blot analysis indicated that calcium was the only divalent cation among those tested that down-regulated omp22 expression. An omp22 mutant was able to grow in calcium-limiting conditions at a rate similar to that of wild-type USDA257. Significantly more nodules were initiated by the omp22 mutant than by the wild-type on soybean cultivar Peking grown in calciumlimiting conditions.

Additional keywords: symbiosis.

Corresponding author: H. B. Krishnan; E-mail: KrishnanH@missouri.edu; Telephone: +1.573.882.8151; Fax: +1.573.884.7850.

This article is in the public domain and not copyrightable. It may be freely reprinted with customary crediting of the source. The American Phytopathological Society, 2005.
Calcium has been shown to play an important role in nodulation. Deficiency of calcium adversely affects infection and nodulation of soybean, trefoil, and alfalfa (Blevins et al. 1977; Caetano-Anollés et al. 1989; Lowther and Loneragan 1968; Munns 1970). Calcium ionophores and chelating agents such as EGTA (ethyleneglycol-bis ( $\beta$-aminoethyl ether)- $N, N, N^{\prime}, N^{\prime}$ tetraacetic acid) and EDTA (ethylenediamineteraacetic acid) adversely affect nodulation (Blevins et al. 1977; Lie and van Egeraat 1988). Calcium requirement for efficient nodulation is especially pronounced at low pH levels (Graham 1992). Alfalfa plants grown at $\mathrm{pH} 6.0$ require 0.1 to $0.2 \mathrm{mM}$ calcium for profuse nodulation. To obtain comparable nodulation at $\mathrm{pH} \mathrm{5.2,}$ the calcium concentration has to be increased to $6.4 \mathrm{mM}$ (Munns 1970). Calcium-deprived Sinorhizobium fredii USDA208 cells were unable to initiate nodules on taproots but formed nodules exclusively on lateral roots (Balatti et al. 1991). Calcium is also required for the optimal growth of rhizobia and influences bacterial multiplication and cell wall integrity (Humphrey and Vincent 1965; Vincent 1962; Vincent and Humphrey 1963). In addition, calcium is known to regulate protein synthesis in rhizobia. Attachment of $R$. leguminosarum bv. viciae to pea root hairs is mediated by rhicadhesin, a calcium-dependent protein (Smit et al. 1987, 1989b). S. fredii USDA208 accumulates an abundant $38-\mathrm{kDa}$ protein when grown in calcium-supplemented medium (Balatti et al. 1991; Krishnan and Pueppke 1993a). NodO and calsymin, which have been suggested to play a role in nodulation, possess calcium-binding activity (de Maagd et al. 1989c; Xi et al. 2000). In addition, calcium is required for maintaining the rigidity of flagella (Robinson et al. 1992).

Sinorhizobium fredii USDA257 is a fast-growing soybean symbiont that forms nitrogen-fixing nodules on primitive soybean cultivars but fails to establish efficient symbiosis with improved North American cultivars (Annapurna and Krishnan 2003; Heron and Pueppke 1984; Keyser et al. 1982). Transposon mutagenesis has delineated a cultivar-specificity locus (nolXWBTUV) that regulates the ability of USDA257 to nodulate advanced cultivars (Heron et al.1989; Meinhardt et al. 1993). This locus has subsequently been identified as part of the type-III protein secretion system (TTSS) (Kovacs et al. 1995; Krishnan et al. 2003). In plant and animal pathogenic bacteria, this specialized secretion system delivers effector proteins into host cells (Galán and Colmer 1999; He 1998; He et al. 2004). USDA257 utilizes the TTSS system to deliver 
nodulation outer proteins (Nops) to the rhizosphere (Krishnan and Pueppke 1993b). Nops can either positively or negatively influence nodulation in a host-dependent manner (Krishnan et al. 2003; Lorio et al. 2004). USDA257 elaborates two types of surface appendages (Krishnan et al. 2003). In the absence of nod-gene-inducing signal molecules, USDA257 produces flagella that are 10 to $12 \mathrm{~nm}$ in diameter. When nod-gene-inducing signal molecules such as genistein or daidzein are present, USDA257 elaborates mostly pili that are 6 to $8 \mathrm{~nm}$ in diameter (Krishnan et al. 2003). Since calcium is known to influence cell surface components and the assembly and rigidity of complex flagella, we were interested in examining the effect of this divalent cation on the surface appendages of USDA257. In the process of characterizing surface appendages of USDA257, we serendipitously discovered the accumulation of a $22-\mathrm{kDa}$ protein in the flagellar preparation of USDA257 grown under low- $\mathrm{Ca}^{2+}$ conditions. Here, we describe the cloning and characterization of a gene encoding this $22-\mathrm{kDa}$ outer membrane protein and its effect on nodulation and cell growth.

\section{RESULTS}

Calcium limitation results in the accumulation of a 22-kDa protein in the flagellar preparation.

To study the effect of calcium on growth of USDA257, the bacteria were cultured on yeast extract mannitol (YEM) medium, which had been formulated to be either calcium-limiting or -sufficient. Morphology of the cells grown under these conditions was examined using cold-field emission scanning elec- tron microscopy. USDA257 cells grown in calcium-limiting conditions were irregular in shape and size (Fig. 1B), while those grown in calcium-sufficient conditions appeared as rodshaped (Fig. 1A). Surface appendages from USDA257 cells grown in calcium-limiting or calcium-sufficient medium were obtained by ultracentrifugation and were examined by transmission electron microscopy. Preparations from USDA257 cells grown in the calcium-sufficient medium contained mostly flagella that displayed a sinusoidal curvature (Fig. 1C). Flagella ends were delineated by a pronounced bending that resembled a hook (Fig. 1C). In sharp contrast, the surface appendages from cells grown in calcium-limiting conditions contained mostly small particles (Fig. 1D). We also examined the protein profiles of surface appendages by sodium dodecyl sulfatepolyacrylamide gel electrophoresis (SDS-PAGE). A flagellar preparation from cells grown in the calcium-sufficient medium revealed the presence of two prominent polypeptides of 34 and $36 \mathrm{kDa}$. Based on their strong cross-reactivity with Sinorhizobium meliloti flagellin antibodies, the $34-$ and $36-\mathrm{kDa}$ proteins were determined to be flagellin subunits (Fig. 2B). Proteins of similar molecular mass were not detected in preparations from cells grown in calcium-limiting conditions, but a $22-\mathrm{kDa}$ protein and a few-high-molecular mass proteins did accumulate (Fig. 2A). Flagellin antibodies also reacted against a $22-\mathrm{kDa}$ protein in a flagellar preparation from cells grown in the calcium-limiting medium (Fig. 2B).

Appearance of a unique 22-kDa protein in calcium-limiting conditions encouraged further studies designed to characterize this calcium-regulated protein. Flagellar preparations obtained
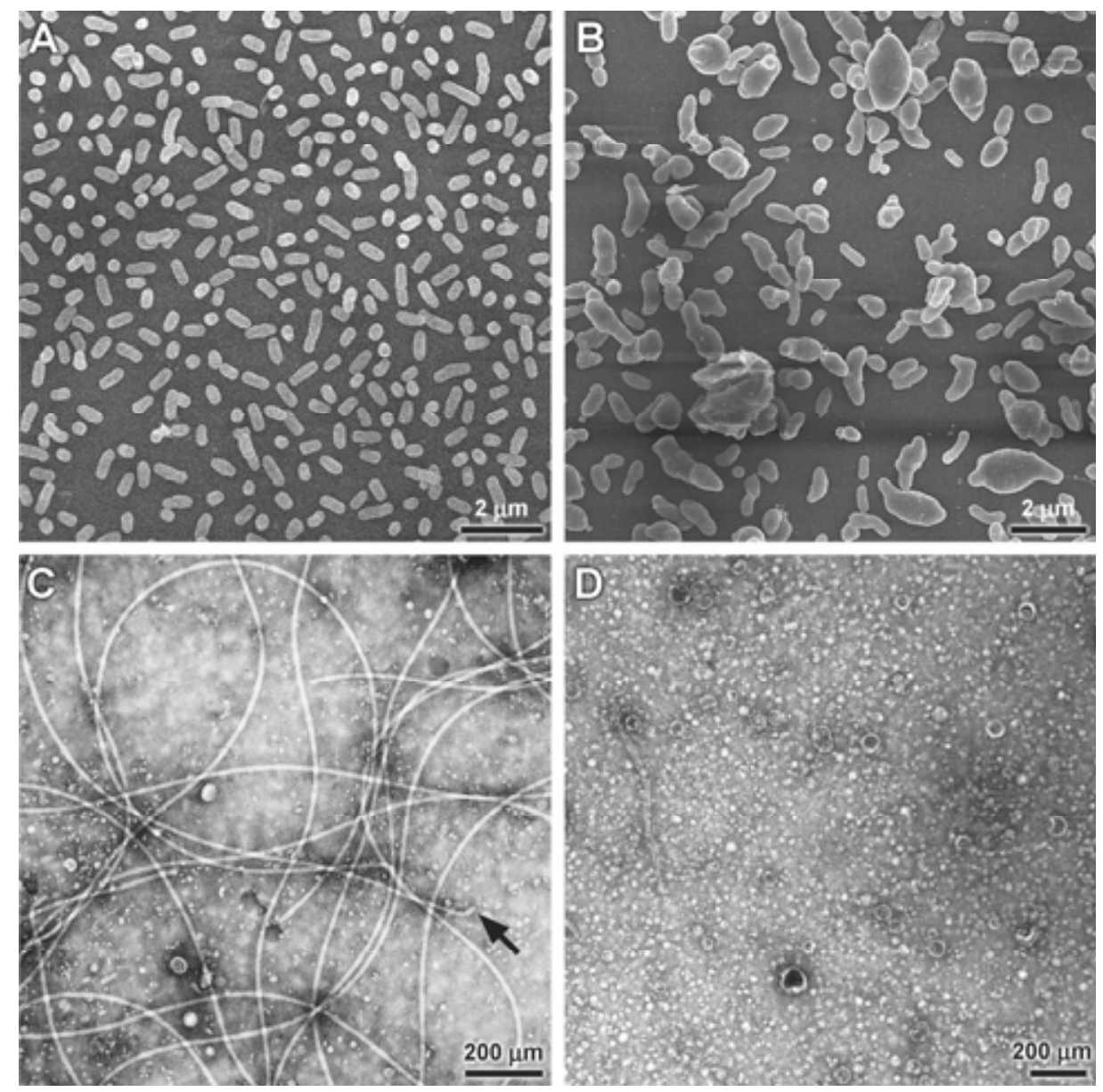

Fig. 1. Cold field scanning electron microscopy observation of USDA257 cells grown in A, calcium-sufficient and B, calcium-limiting media. Note the cells grown in calcium-limiting media have irregular cell shape and size. Transmission electron micrographs of flagellar preparation of USDA257 grown in C, calcium-sufficient and $\mathbf{D}$, calcium-limiting media. The flagellar preparations were stained with $1 \%$ phosphotungstic acid (pH 6.5). 
from 100-ml cultures of cells grown under calcium-limiting conditions were resolved by preparative gel electrophoresis, and the 22-kDa band was excised and subjected to N-terminal amino acid analysis. The determined sequence, ADAVDEVPAAPAAEYTDPAV, was used in a basic local alignment search tool (BLAST) search of the National Center for Biotechnology Information protein database. The peptide sequence showed significant homology to that of a putative outer membrane protein of S. meliloti.

\section{Cloning and nucleotide sequence of omp22.}

To isolate the omp22 coding sequence from USDA257 genomic DNA, we synthesized primers corresponding to the $\mathrm{N}$ and C-terminal coding regions of the S. meliloti omp gene (accession number AL591786). These primer sequences were used for polymerase chain reaction (PCR) amplification of a corresponding fragment using USDA257 genomic DNA as the template. Sequencing showed this fragment to contain the omp 22 coding region. To obtain regulatory regions of the gene, we screened a cosmid library of USDA257 with a radiolabeled omp 22 PCR product. Four positive cosmid clones were identified. Southern blot analysis revealed that all four cosmid clones contained a 6-kb BamHI/EcoRI fragment. We subsequently purified this hybridizing fragment and subcloned it into pBS generating the plasmid pOMP3 (Fig. 3A). Using this plasmid, the complete nucleotide sequence of omp22 was determined. When this sequence was analyzed, one full-length open reading frame (ORF) was identified (Fig. 3B). The predicted ORF consists of $639 \mathrm{bp}$ and codes for a protein with a molecular mass of 21,677 Da. The N-terminal sequence of the purified protein matched exactly with the deduced protein se-

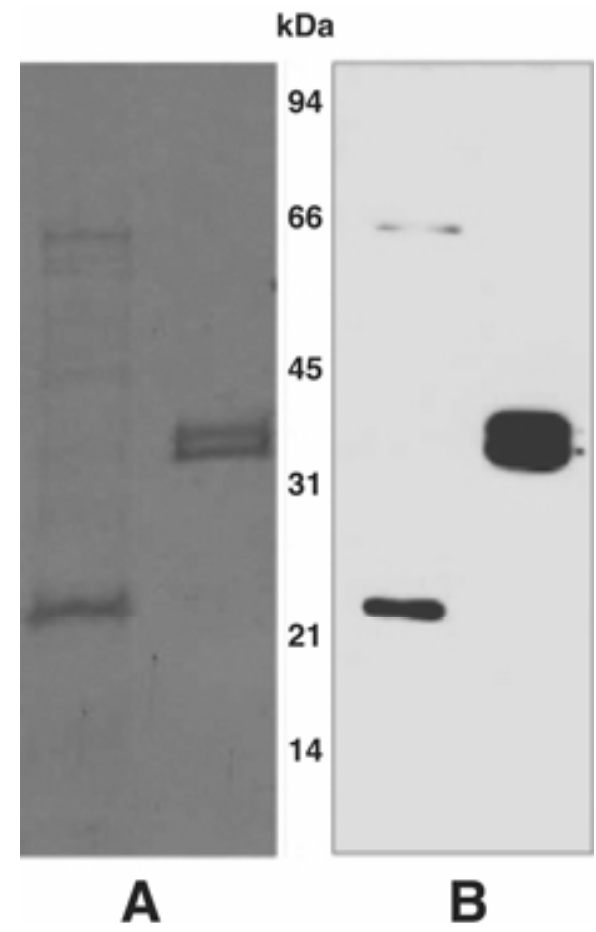

Fig. 2. A, Sodium dodecyl sulfate-polyacrylamide gel electrophoresis (SDS-PAGE) and $\mathbf{B}$, immunoblot analysis of flagellar preparations obtained from USDA257 cells grown in calcium-limiting (lane 1) and calcium-sufficient (lane 2) media. Proteins were resolved on $12.5 \%$ SDSPAGE gels and were stained with Coomassie brilliant blue (A). Proteins from a similar gel was electrophoretically transferred to a nitrocellulose membrane and was probed with antibodies raised against Sinorhizobium meliloti wild-type flagella. Immunoreactive polypeptides were detected by chemiluminescence. Molecular mass marker sizes (in $\mathrm{kDa}$ ) are shown between the two panels. quence from positions 21 to 40, indicating that the first 20 amino acids serve as a signal peptide (Fig. 3B). Signal sequence removal results in a mature $19.3-\mathrm{kDa}$ protein. However, this protein migrates on SDS-PAGE, with a molecular mass of approximately $22 \mathrm{kDa}$ (Fig. 2). NodO and calsymin, two calciumbinding secreted proteins, have also been shown to exhibit aberrant migration on SDS-PAGE (de Maagd et al. 1989c; Xi et al. 2000). It is speculated that posttranslational modification, low SDS-binding capacity, or the acidic nature of the protein contributes to aberrant migration. At present, we do not know if the preceding factors play a role in aberrant migration of Omp22. BLAST searches of protein databases showed that Omp22 has several bacterial homologs. S. meliloti, Agrobacterium tumefaciens, Rhizobium leguminosarum bv. viciae, and Brucella suis homologs share 91, 55, 51, and $40 \%$ identity to that of USDA257 Omp22, respectively. Each of these outer membrane proteins has a phenylalanine residue at the carboxy terminus, which is necessary for correct assembly (Struyvé et al. 1991).

\section{Expression of Omp22 in Escherichia coli.}

To express USDA257 Omp22 in E. coli, the coding region was placed under control of the $\mathrm{T} 7$ promoter. The resulting construct added six histidine residues to the $\mathrm{C}$-terminal region. Expression of recombinant Omp22 was initiated by the addition of $1 \mathrm{mM}$ isopropyl- $\beta$-D-thiogalactoside (IPTG) to the growth medium. SDS-PAGE of total protein from IPTGinduced cells revealed accumulation of a 22-kDa protein not present in noninduced cultures (Fig. 4). Recombinant Omp22 was purified from the total protein cell extracts using nickelaffinity column chromatography. SDS-PAGE of affinity-purified 22-kDa Omp22 revealed the presence of minor contaminating proteins. Further purification was achieved by preparative SDS-PAGE, yielding protein of sufficient purity for the production of polyclonal antibodies.

\section{Subcellular localization of Omp22.}

To determine specific localization of USDA257 Omp22, cells were grown in calcium-limiting conditions and were divided into soluble, membrane, periplasmic and extracellular fractions. Proteins were separated by SDS-PAGE and were stained with silver (Fig. 5A). Observation revealed that the 22$\mathrm{kDa}$ protein was not a major component of the preceding fractions. However, when Western blot analysis was performed using antibodies generated against the recombinant protein, USDA257 Omp22 was clearly enriched in the membrane and extracellular fractions. Accumulation of Omp22 was greatest in the extracellular fraction when compared with all other fractions (Fig. 5B). We also performed immunocytochemical studies on resin-embedded thin sections of USDA257 cells to confirm the subcellular location of the $22-\mathrm{kDa}$ protein. When thin sections were treated with preimmune serum and protein Agold particles, no specific labeling was detected (Fig. 6B). Conversely, when antibodies raised against the recombinant 22 $\mathrm{kDa}$ were employed, specific labeling of protein A-gold particles was seen on the secreted material, located proximal to the cell (Fig. 6A). Deposition of protein A-gold particles was seen only in confined regions of the cell membrane. The lack of labeling throughout the cell membrane may be due to low abundance of Omp22 in these regions, since subcellular localization studies indicate that most of the Omp22 accumulates in the extracellular medium, when grown in a calcium-limiting condition.

Immunological detection of Omp22 in other rhizobia.

Since the amino acid sequence of Omp22 of USDA257 and RopB of R. leguminosarum share $51 \%$ sequence identity, we 

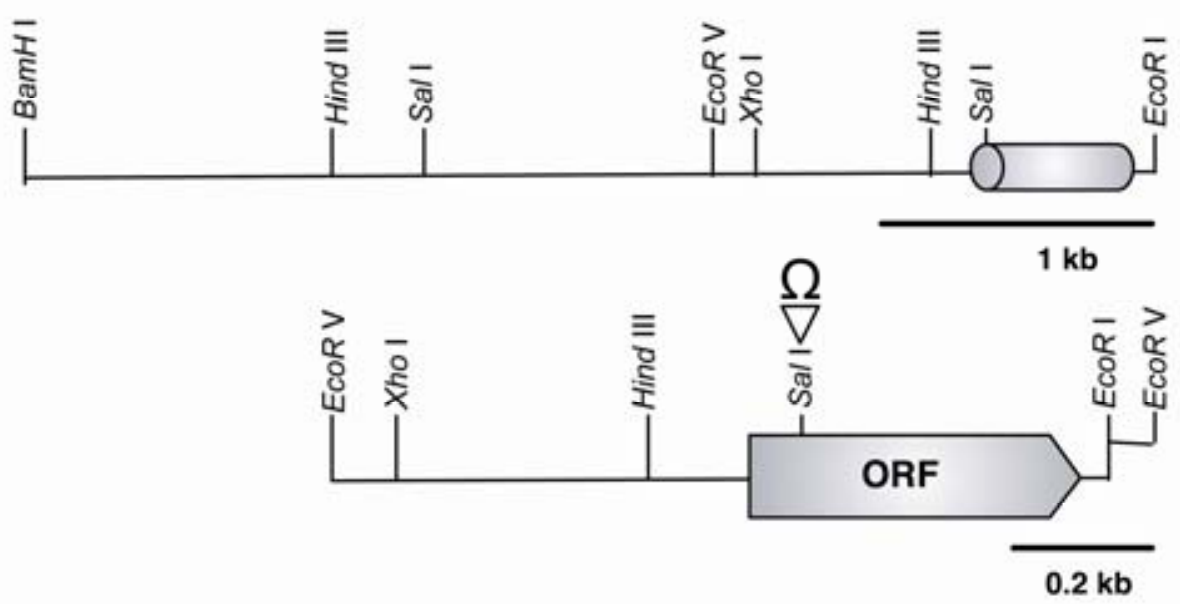

B

1 aagcttgaaacatagttaataaatcctctgtgtcgccaaggcaacatcaaattttggacgtgcttgcgccactaaaatttcacatttta 90 gctcttgtgaatccgcaatttctatccaatttccggtcaaccggacgggttaattgtagatacccggtgtcccgataaagcacgccaaag 180 agatgettcggagegecggtetgaaaggagaatagtATGCGTACGCTCACCACCACCCTCATGGCTTCGGCCATCGCCCTGGTCGCCTTG $\begin{array}{lllllllllllllllllllllllll}M & R & \text { T } & \text { L } & \text { T } & \text { T } & \text { T } & \text { L } & \text { M } & \text { A } & \text { S } & \text { A } & \text { I } & \text { A } & \text { L } & \text { V } & \text { A } & \text { L }\end{array}$

270 CAGGCAGCTCATGCCGCTGACGCCGTCGACGAGGTTCCGGCTGCTCCGGCTGCCGAATATACCGACCCGGCCGTGAAGAACTGGTCCGGC $\begin{array}{llllllllllllllllllllllllllllll}\mathbf{C} & \mathbf{A} & \mathbf{A} & \mathbf{H} & \mathbf{A} & \mathbf{A} & \mathbf{D} & \mathbf{A} & \mathbf{V} & \mathbf{D} & \mathbf{E} & \mathbf{V} & \mathbf{P} & \mathbf{A} & \mathbf{A} & \mathbf{P} & \mathbf{A} & \mathbf{A} & \mathbf{E} & \mathbf{Y} & \mathbf{T} & \mathbf{D} & \mathbf{P} & \mathbf{A} & \mathbf{V} & \mathbf{K} & \mathbf{N} & \mathbf{W} & \mathbf{S} & \mathbf{G}\end{array}$ 360 GCCTATGTCGGCGGCACGGCGAATTGGCATCACGGCGAAGCCGATGCCACCGGCGGCAATACGTCAGCCGGCTTTGGCGGTGGTCTTTAC $\begin{array}{lllllllllllllllllllllllllllllll}\text { A } & \text { Y } & \text { V } & \text { G } & \text { G } & \text { T } & \text { A } & \text { N } & \text { W } & \text { H } & \text { H } & \text { G } & \text { E } & \text { A } & \text { D } & \text { A } & \text { T } & \text { G } & \text { G } & \text { N } & \text { T } & \text { S } & \text { A } & \text { G } & \text { F } & \text { G } & \text { G } & \text { G } & \text { L } & \text { Y }\end{array}$

450 GGCGGCTACAACGTGCAGGACGGCCAGATGGTCTACGGTGGCGAAGCCGACGTCAACTATGCCGGCAACGACTCGCACTCCAGCGGTCGC

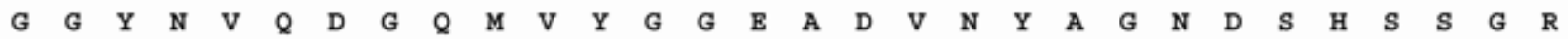

540 CGCGTCAAGCAGGGCGTCAATGGCTCGGTCCGCGGCCGTGTCGGTGTCGATCTGAATCCTGTCCTGGTATACGGCACCGCCGGTCTCGCC $\begin{array}{lllllllllllllllllllllllllllllll}R & \text { V } & \text { K } & \text { Q } & \text { G } & \text { V } & \text { N } & \text { G } & \text { S } & \text { V } & \text { R } & \text { G } & \text { R } & \text { V } & \text { G } & \text { V } & \text { D } & \text { L } & \text { N } & \text { P } & \text { V } & \text { L } & \text { V } & \text { Y } & \text { G } & \text { T } & \text { A } & \text { G } & \text { L } & \text { A }\end{array}$

630 CTTGGCAATGCCAAGCTCTCGACCCCGGCAGGTTCCGACGACAAGACCCTCGTCGGCTGGACGGCTGGCGCCGGTGCCGAAACCTTCGTC

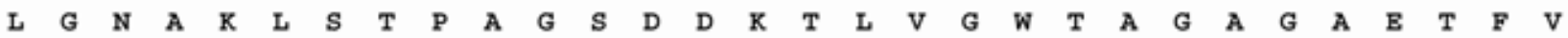

720 ACCGACAACGTCACCGCTCGCGTCGAGTACCGCTACACGGACTATGCCTCGAAGGACTTCCGCACCGGCGGCTCGACCGTCTCGTCCGGC

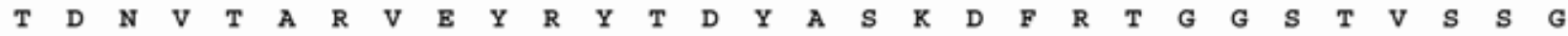

810 TATGACGAGCACAGCGTCAAACTCGGTATGGGCGTCAAGTTCTGAtccgacaaatggatcgaaaaggecggggcgacccggcettttt

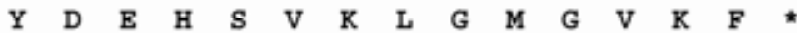

900 catgectgaacttegtttgaattc $\quad 926$

C

S. fredii
S. meliloti
A. tumefaciens
R. leguminosarum
B. suis
S. fredii
S. meliloti
A. tumefaciens
R. leguminosarum
B. suis
S. fredii
S. meliloti
A. tumefaciens
R. leguminosarum
B. suis
S. fredii
S. meliloti
A.tumefaciens
R. leguminosarum
B. suis

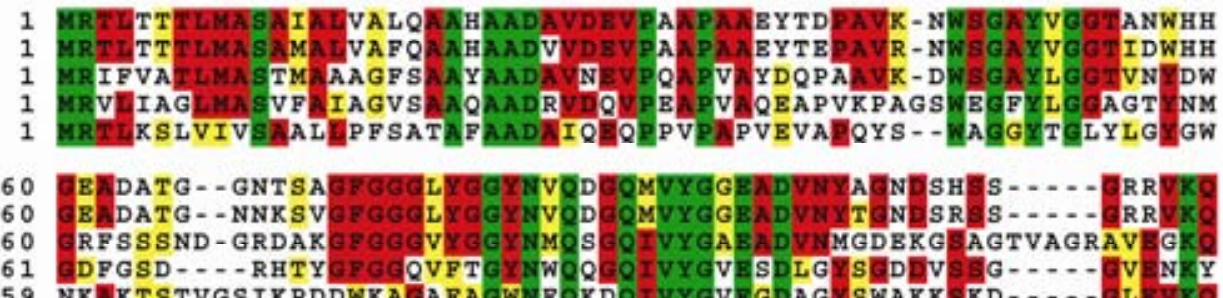
59 NK DKTSTVGSIKPDDWKAGAFA GWNFQKDQIVYGVEGDAGXSWAKK

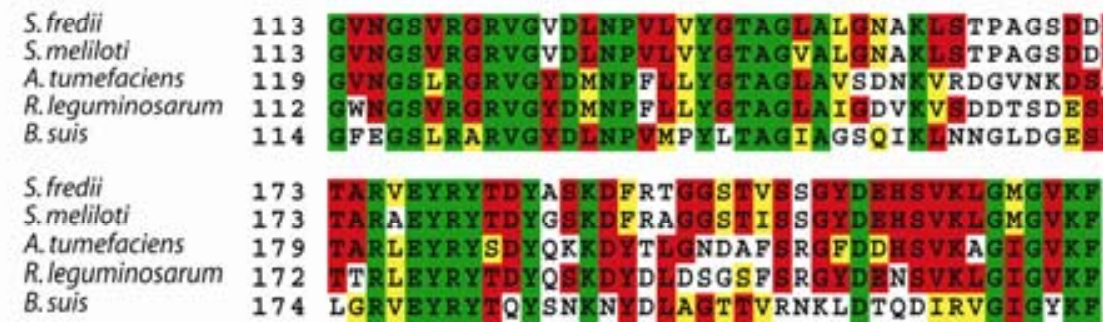

Fig. 3. A, Restriction map of the DNA fragment that contains the gene encoding the 22-kDa calcium-regulated protein. The orientation of the open reading frame and the site of omega cassette insertion are also shown. B, Sequence of the omp22 of USDA257. The predicted amino acid sequence is given below the nucleotide sequence. The N-terminal sequence of the purified 22-kDa protein is underlined. Opposing arrows positioned at the end of the open reading frame indicate inverted repeat sequences. C, Alignment of the amino acid sequence of the 22-kDa USDA257 calcium-regulated protein with homologous sequences from other bacteria, using the ClustalW program. Dashes indicate gaps to facilitate best alignment. Green shading indicates conserved residues; red shading indicates residues showing more than $60 \%$ identity; yellow shading indicates those residues showing more than $60 \%$ similarity. The protein sequences used for the alignment can be found in the Swiss-Prot/TrEMBL protein database with the following accession numbers: Sinorhizobium fredii, Q7X4Z6; Sinorhizobium meliloti, Q92QX0; Agrobacterium tumefaciens, Q7CZX2; Rhizobium leguminosarum bv. viciae, Q52866; and Brucella suis, Q45689. 
wanted to investigate whether Omp22 antibodies could recognize the RopB protein. In addition, we wanted to examine whether proteins related to Omp22 were also present in diverse groups of rhizobia. To test this possibility, we performed Western blot analysis, using total proteins isolated from $S$. fredii USDA205, S. terangae, S. meliloti, S. saheli, S. medicae, $R$. leguminosarum, R. mongolense, Azorhizobium caulinodans, and Mesorhizobium amorphae (Fig. 7). USDA257 Omp22 antibodies were able to recognize immunologically related proteins from all rhizobia used in this study except Azorhizobium caulinodans. Two polypeptides that cross-reacted with USDA257 Omp22 antibodies were detected in R. leguninosarum total protein extracts. Interestingly, the cross-reaction to the RopB $(22 \mathrm{kDa})$ was much weaker than that observed with the 32-kDa protein (Fig. 7). A broad band of immunoreactive polypeptides ranging from 30 to $45 \mathrm{kDa}$ was detected in $M$. amorphae. These observations indicate that proteins immunologically similar to USDA257 Omp22 are present in a diverse group of rhizobia.

\section{Calcium reduces the transcription of the omp22.}

To examine the effect of calcium on Omp22 accumulation, we grew USDA257 in the presence of increasing calcium concentrations. Total and extracellular proteins from treatments were examined by Western blot analysis (Fig. 8A and B). Antibodies raised against the purified recombinant Omp22 reacted specifically against a $22-\mathrm{kDa}$ protein present in total and extracellular fractions. Increasing calcium concentrations resulted in a substantial decrease in Omp22 accumulation (Fig. 8A and B). Clearly, Omp22 accumulation was several-fold greater in

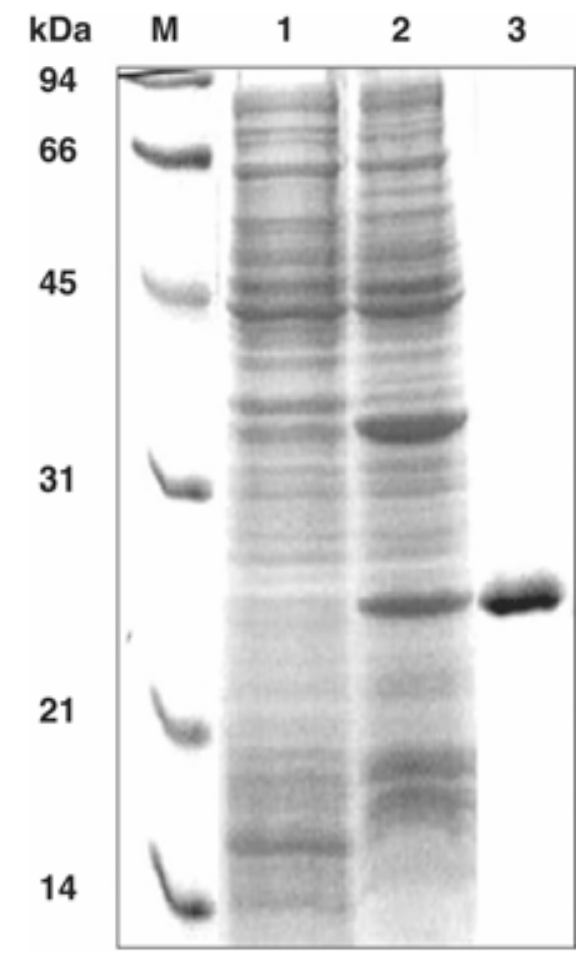

Fig. 4. Expression of the USDA257 22-kDa calcium-regulated protein in Escherichia coli. The coding region of the 22-kDa protein was cloned into the expression vector pET28 (a)+ and was introduced into E. coli ER2566. Protein expression was achieved by addition of $1 \mathrm{mM}$ isopropyl- $\beta$-D-thiogalactoside (IPTG), and the recombinant protein was purified nickel-affinity agarose column chromatography. E. coli proteins were separated by sodium dodecyl sulfate-polyacrylamide gel electrophoresis and were visualized by staining with Coomassie brilliant blue. Lane 1, total protein from noninduced cells; Lane 2, total protein from IPTG-induced cells; Lane 3, purified recombinant USDA257 calcium-regulated protein. Lane M shows protein molecular mass markers whose sizes are indicated in $\mathrm{kDa}$. extracellular media as compared with the total cell protein fraction (Fig. 8A and B). Northern blot analysis was performed to determine if calcium-mediated reduction in Omp22 accumulation was regulated at the transcriptional level (Fig. 8C). A probe consisting of a 639-bp fragment of USDA257 omp22 coding region showed strong hybridization with an approximately 0.9-kb RNA transcript (Fig. 8C). The intensity of the hybridization signal was considerably lower in an RNA preparation obtained from cells grown in the calcium-sufficient medium. Calcium was the only divalent cation among those tested that had a negative effect on omp22 transcript levels (Fig. 8C).

\section{Omp22 is not required for growth of USDA257} in calcium-limiting condition and does not bind calcium.

To investigate the function of omp22, we created a mutant by introducing a spectinomycin-resistant omega cassette (Prentki and Krisch 1984) into the SalI site located near the $5^{\prime}$ region of the gene (Fig. 3A). Inactivation of omp22 was confirmed by Southern blot analysis. In addition, we performed Western blot analysis to confirm successful creation of the omp 22 mutant. Antibodies raised against Omp22 failed to recognize the corresponding protein from the mutant. Introduction of a plasmid that carries the promoter and coding sequences of USDA257 omp22 (pOMP-5) into the mutant restored the production of the 22-kDa protein (data not shown). To determine if Omp22 plays a role in USDA257 growth, we compared the omp22 mutant's ability to grow in either calcium-limiting or calciumsufficient medium with that of the wild-type parent. Both the wild type and the omp 22 mutant exhibited similar growth curves, indicating that Omp22 was not essential for growth of bacteria under calcium-limiting conditions (Fig. 9). Since Omp22 accumulates in the extracellular media when USDA257 is grown in calcium-limiting conditions, we wanted to examine if Omp22 may be involved in scavenging calcium. We performed ${ }^{45} \mathrm{Ca}^{2+}$-binding assays using purified native re-

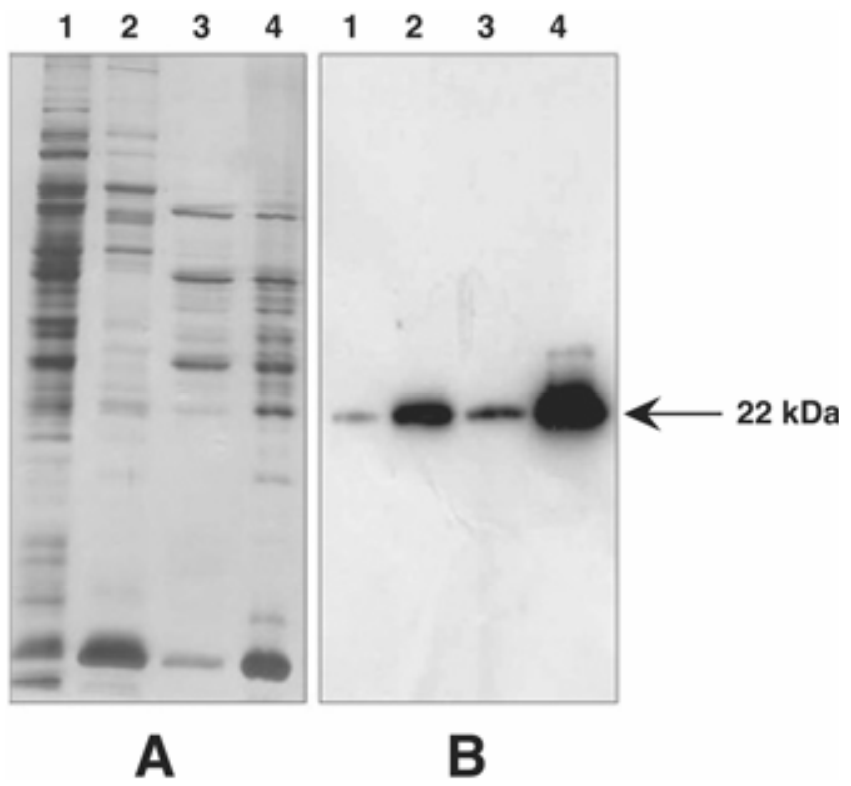

Fig. 5. Subcelluar localization of the $22-\mathrm{kDa}$ calcium-regulated protein. Proteins isolated from USDA257 cells grown in calcium-limiting conditions were fractionated into soluble (lane 1), membrane (lane 2), periplasmic (lane 3), and extracellular (lane 4) fractions and were separated on a $12.5 \%$ sodium dodecyl sulfate-polyacrylamide gel electrophoresis. The resolved proteins were either $\mathbf{A}$, silver stained or $\mathbf{B}$, transferred to nitrocellulose and were probed with antibodies raised against the $22-\mathrm{kDa}$ protein. Immunoreactive polypeptides were detected by chemiluminescence. 
combinant Omp22 and detected no evidence of ${ }^{45} \mathrm{Ca}^{2+}$ binding to Omp22. Under identical conditions, calcium binding to parvalbumin, a previously demonstrated calcium-binding protein, was detected (data not shown).

\section{Symbiotic ability of USDA257 Omp22 mutant.}

The ability of the USDA257 omp22 mutant and the wildtype parent to form nodules on soybean cultivar Peking was examined in plastic growth pouches. After inoculation, plants were watered with either sterile water or sterile water containing $100 \mu \mathrm{M}$ EGTA (ethylene glycol-bis( $\beta$-aminoethyl ether)$N, N, N^{\prime}, N^{\prime}$-tetraacetic acid). Analysis of nodulation kinetics indicated that when plants were watered with $100 \mu \mathrm{M}$ EGTA, the USDA257 omp22 mutant was more efficient than the wild type in initiating nodulation. Ten days after inoculation, the omp22 mutant exhibited $3.8 \pm 0.5$ nodules per plant, while the wild-type had $2.0 \pm 0.2$ nodules per plant. By 20 days after inoculation, the omp 22 mutant produced $7.2 \pm 0.6$ nodules per plant, while the wild-type USDA257 formed $5.6 \pm 1.2$ nodules per plant. This difference in nodulation kinetics, however, was not evident when the plants were watered with sterile water. We also performed Western blot analysis to determine if Omp22 could be detected in soybean nodules. Omp22 antibodies did not react against any protein from the nodule extract isolated from 10- and 20-day-old soybean nodules initiated by USDA257 and the omp22 mutant (data not shown). This observation indicates that Omp22 does not accumulate in soybean nodules.

\section{DISCUSSION}

Cell surface components, including outer membrane proteins of rhizobia, have been shown to be influenced by calcium (Balatti et al. 1991; Smit et al. 1987, 1989a). Outer membrane proteins of free-living $R$. leguminosarum bv. viciae 248 have been intensely studied (de Maagd et al. 1989a and b; 1992, 1994; Roest et al. 1995a and b) and classified as belonging to one of four antigen groups, I to IV. Two genes, ropA and ropB, which code for $36-\mathrm{kDa}$ group III and $22-\mathrm{kDa}$ group II outer membrane proteins, have been cloned and characterized (de
A
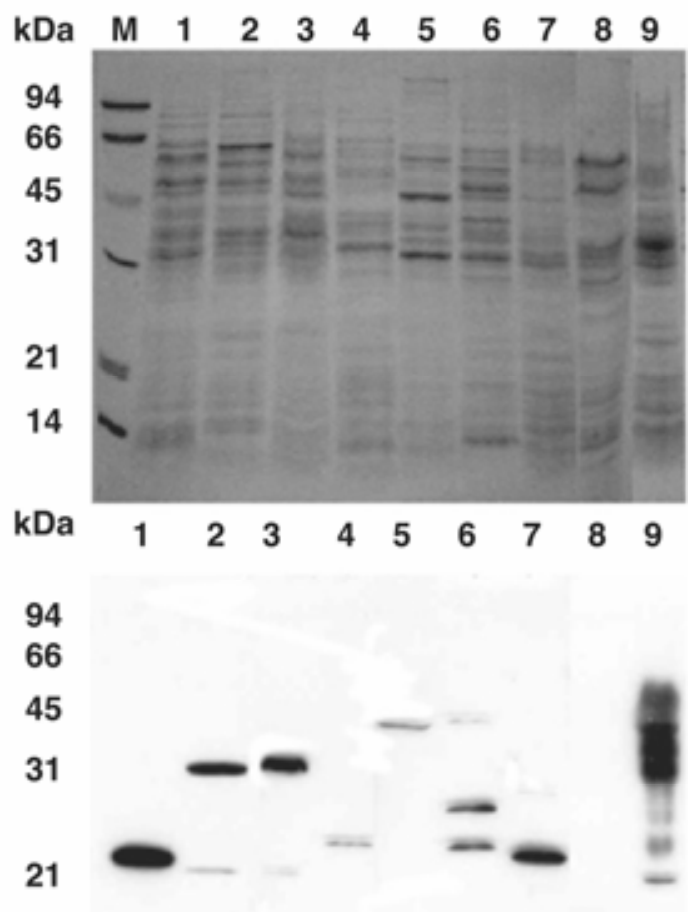

14

Fig. 7. Immunological detection of Omp22-related proteins in diverse rhizobia. Total protein extracted from Sinorhizobium fredii USDA205 (lane 1), S. terangae (lane 2), S. meliloti (lane 3), S. saheli (lane 4), S. medicae (lane 5), Rhizobium leguminosarum (lane 6), R. mongolense (lane 7), Azorhizobium caulinodans (lane 8) and Mesorhizobium amorphae (lane 9) were analyzed by sodium dodecyl sulfate-polyacrylamide gel electrophoresis. Rhizobia were grown in yeast extract mannitol media except A. caulinodans, which was grown in yeast extract glutamate medium under calcium-limiting conditions. A, The protein profile as visualized by Coomassie brilliant blue. B, The Western blot was probed with USDA257 Omp22 antibodies and immunoreactive polypeptides were detected by chemiluminescence. The sizes of the molecular mass markers in $\mathrm{kDa}$ are shown in lane $\mathrm{M}$.
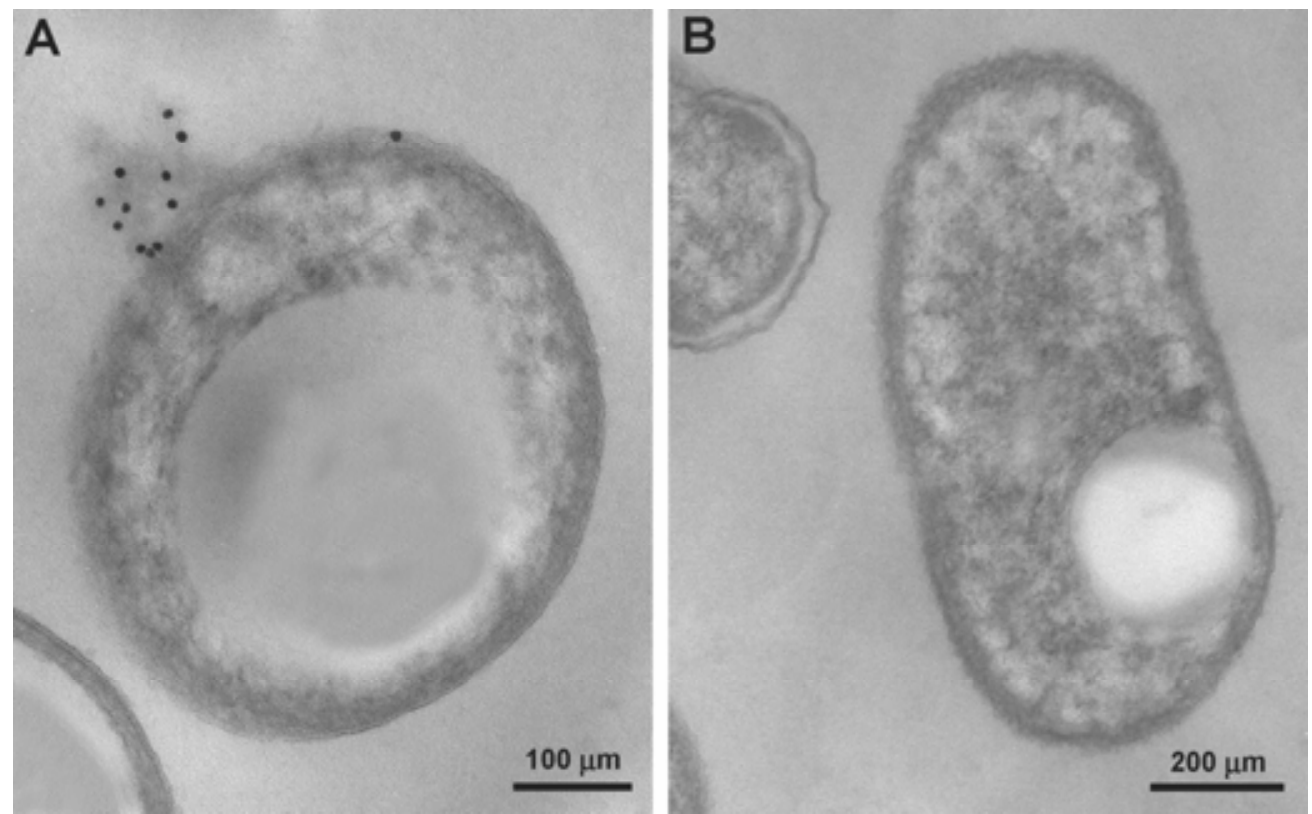

Fig. 6. Immunocytochemical localization of the $22-\mathrm{kDa}$ calcium-regulated protein. USDA257 cells grown in calcium-limiting conditions were fixed, dehydrated, and infiltrated with Spurr's resin. Thin sections were incubated with antibodies specific for A, the 22-kDa protein or B, preimmune serum, followed by incubation with $10 \mathrm{nmol}$ protein A-gold particles. 
Maagd et al. 1992; Roest et al. 1995b). USDA257 Omp22 shares greater than $90 \%$ homology with a deduced protein encoded by an uncharacterized ORF from $S$. meliloti. It also shows considerable homology with RopB of $R$. leguminosarum and AopB of Agrobacterium tumefaciens (Jia et al. 2002). Each of these proteins is synthesized with a conserved N-terminal signal sequence required for transport across the cytoplasmic membrane. The presence of membrane-spanning $\beta$ sheets and a terminal phenylalanine residue are characteristic features of these and other outer membrane proteins. The biochemical function of neither RopB nor AopB has been clearly defined. It is speculated that these proteins may play a critical role in plant-microbe interactions. These proteins may also have pore-forming activity and may be involved in transporting sugar molecules across the outer membrane (Jia et al. 2002). It remains to be determined if USDA257 Omp22 possesses any of these functions.

Subcellular fractionation and immunocytochemical localization studies reveal that USDA257 Omp22 primarily accumulates in the extracellular fraction. Since Omp22 shares several characteristic features of outer membrane proteins, its presence in the extracellular fraction is intriguing. The $22-\mathrm{kDa}$ protein accumulates in the extracellular fraction only when USDA257 is grown in calcium-limiting conditions. Calcium has been shown to promote both oligomerization of outer membrane proteins and their covalent attachment to the peptidoglycans (de Maagd et al. 1989b). Our studies show that calciumdeprived USDA257 cells have an irregular shape presumably due to loss of cell wall integrity. We hypothesize that the oligomerization of Omp22 and its association with peptidoglycans is compromised in calcium-limiting conditions, resulting in accumulation of this protein in the extracellular medium.

Calcium-regulated proteins have been detected in different rhizobia, and some of these proteins are thought to be involved in nodulation (Economou et al. 1990; Smit et al. 1989b; Xi et al. 2000). The function of Omp22 in nodulation is not clear. Our studies indicate that Omp22 is dispensable for nodulation of soybean cultivar Peking under normal growing conditions. However, the omp22 mutant was able form a greater number of nodules on Peking soybean when grown in calcium-limiting conditions. The reason for this increase in nodulation remains to be elucidated. A possible explanation is that the omp22 mutant may have altered Nops secretion due to loss of membrane integrity when grown under calcium-limiting conditions. It has been well established that Nops are involved in regulating nodulation in a host-dependent manner (Krishnan et al. 2003; Lorio et al. 2004; Marie et al. 2001, 2003; Viprey et al. 1998). Clearly, more studies are required to determine if omp22 is involved in Nops secretion.

Earlier studies have clearly established growth-dependent changes in some outer membrane protein antigens of $R$. leguminosarum (de Maagd et al. 1989a, 1992, 1994). Immunological studies using polyclonal and monoclonal antibodies raised against cell envelope fractions of $R$. leguminosarum have shown that group II and III outer membrane proteins were not expressed in bacteroids isolated from pea nodules (de Maagd et al. 1989a). Interestingly, it has been shown that group II antigens decrease in bacteroids of both determinate and indeterminate nodules, and this decrease was independent of nitrogen fixation (Roest et al. 1995a). In this study, we observed that USDA257 Omp22 was not expressed in soybean nodules. Downregulation of group II antigens during bacteroid development is not fully understood. Attempts to identify signals or recreate physiological conditions required to lower the expression of $\mathrm{rop} B$ in free-living conditions have not been successful (Roest et al. 1995b). However, results presented in this study indicate that calcium may function as one of the contributing signal molecules. Addition of calcium to the culture medium clearly lowered the transcription of USDA257 omp22. The calcium concentration within the symbiosome space has been reported to be high (Udvardi and Day 1997), and this could play a role in lowering the transcription of omp22. Clearly, further studies are required to elucidate the regulation of USDA257 omp 22 by calcium in both free-living and symbiotic conditions.

Assembly and functionality of the bacterial flagella have been linked to presence of divalent cations (Robinson et al. 1992). Bacterial flagella are of two distinct types, plain or complex (Götz et al. 1982; Joys 1988; Schmitt et al. 1974). Plain flagella appear as smooth-surfaced filaments, while complex exhibit a topology of helical ridges and grooves that appear as crosshatches in electron micrographs. Soil bacteria $S$.

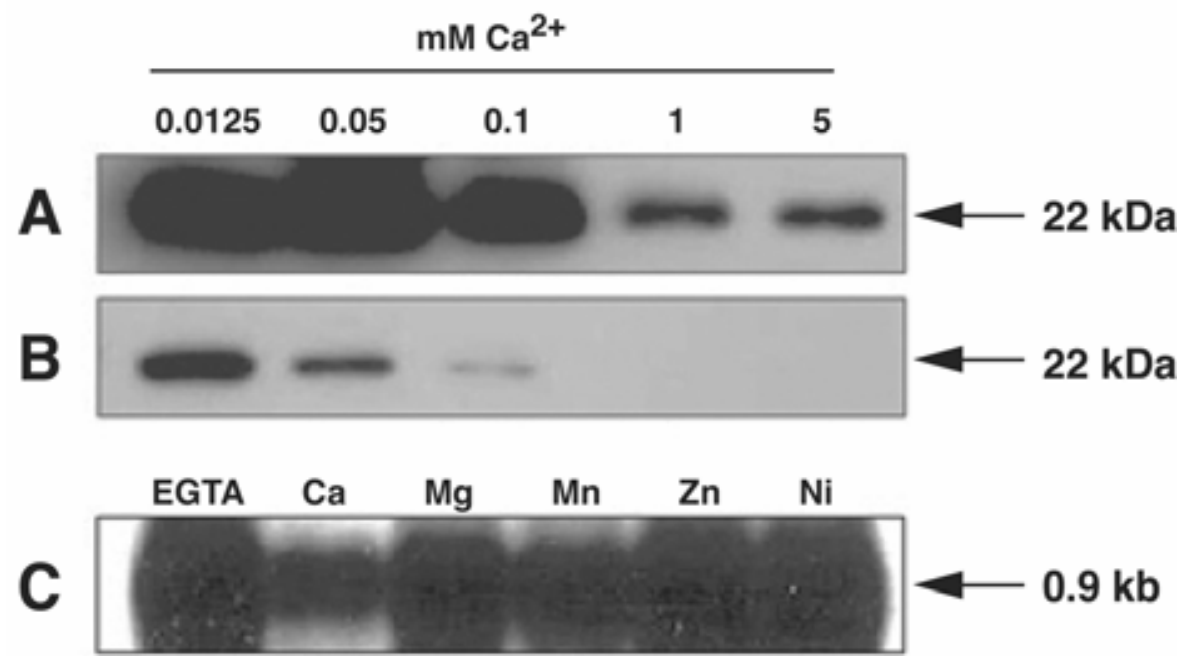

Fig. 8. Calcium decreases the accumulation of Omp22 and the transcription of omp22. Proteins were isolated from an equal number of bacterial cells. A, Extracellular and B, total cell proteins from USDA257 cells that were grown in the presence of increasing calcium (lanes 1 to 5) were resolved by sodium dodecyl sulfate-polyacrylamide gel electrophoresis, were transferred to a nitrocellulose membrane, and were probed with USDA257 Omp22 antibodies. C, Northern blot analysis. RNA, isolated from bacteria grown in the presence of various divalent cations, was resolved on a formaldehyde agarose gel and was transferred to a nylon membrane. Blot was hybridized with radiolabeled USDA257 omp22 coding region. Note that, among the divalent cations examined, only calcium down-regulated expression of omp22. 
meliloti, R. lupine, Bradyrhizobium japonicum, and Pseudomonas rhodos exhibit the more rigid complex flagella, an attribute that could enhance motility in the soil fluid environment (Götz et al. 1982; Krupski et al. 1985; Maruyama et al. 1978; Schmitt et al. 1974). Electron microscopic observation reveals that USDA257 produces flagella that lack the crosshatched appearance of complex flagella filaments and, thus, can be classified as plain. In $S$. meliloti, which produces complex flagella, it has been proposed that calcium may promote interchain

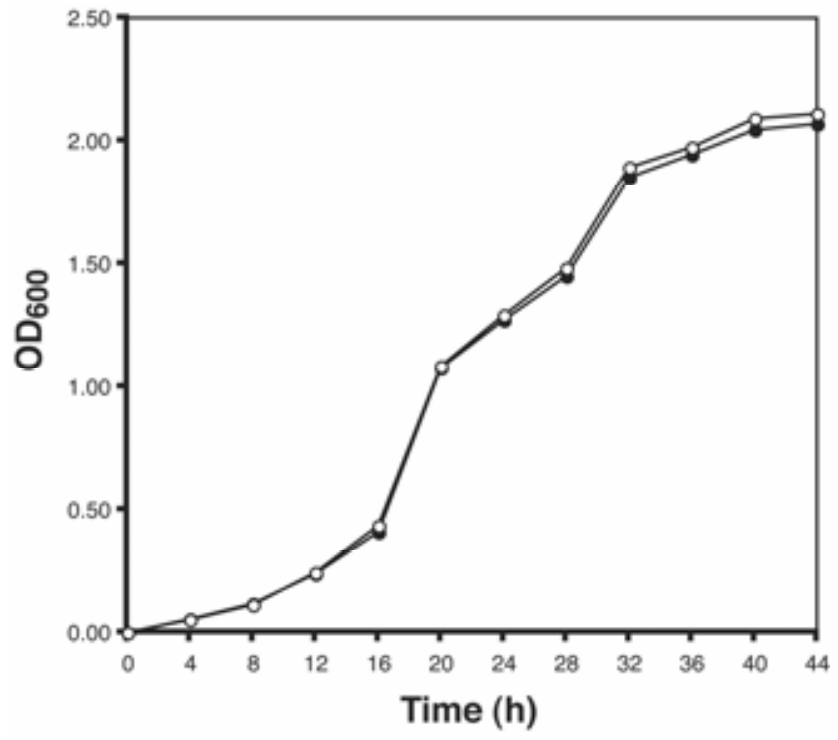

Fig. 9. Growth curves of USDA257 (O) and the omp22 mutant (•). Cells were grown at $30^{\circ} \mathrm{C}$ in yeast extract mannitol medium under calciumlimiting conditions. association between flagellin monomers. In contrast, $R$. leguminosarum 8401, which lacks complex flagellar filaments, calcium does not seem to be involved in maintaining the integrity of flagella, since no disassociation of flagellin was observed when they were exposed to EDTA (Robinson et al. 1992). These observations suggest that calcium is required for association of flagellin monomers in organisms that produce complex flagella. Our observation that USDA257 loses its flagellar integrity in the presence of EGTA suggests that calcium may also be involved in maintaining the integrity and function of plain flagella.

\section{MATERIALS AND METHODS}

Bacterial strains, plasmids, and growth condition.

Bacterial strains and plasmids used in this study are shown in Table 1. E. coli strains were cultured in Luria-Bertani medium at $37^{\circ} \mathrm{C}$ (Sambrook et al. 1989), and rhizobia were grown in YEM broth (Vincent 1970) at $30^{\circ} \mathrm{C}$. When required, antibiotics were added at the following concentrations: kanamycin, $50 \mu \mathrm{g} / \mathrm{ml}$; tetracycline, $10 \mu \mathrm{g} / \mathrm{ml}$; spectinomycin, $50 \mu \mathrm{g} / \mathrm{ml}$; and ampicillin $100 \mu \mathrm{g} / \mathrm{ml}$. Calcium-sufficient YEM medium was made by adding calcium chloride to give a final concentration of $1 \mathrm{mM}$. A calcium-limiting medium was generated by adding chelating agent EGTA to a final concentration of 100 $\mu \mathrm{M}$ (Balatti et al. 1991).

\section{Molecular techniques.}

Recombinant DNA techniques were performed according to established protocols (Sambrook et al. 1989). Construction of a USDA257 genomic cosmid library and subsequent screening were performed as described (Heron et al. 1989). DNA sequencing was performed at the University of Missouri DNA Core facility (Columbia, MO, U.S.A.). Plasmid DNA isolation,

Table 1. Bacterial strains and plasmids used in this study

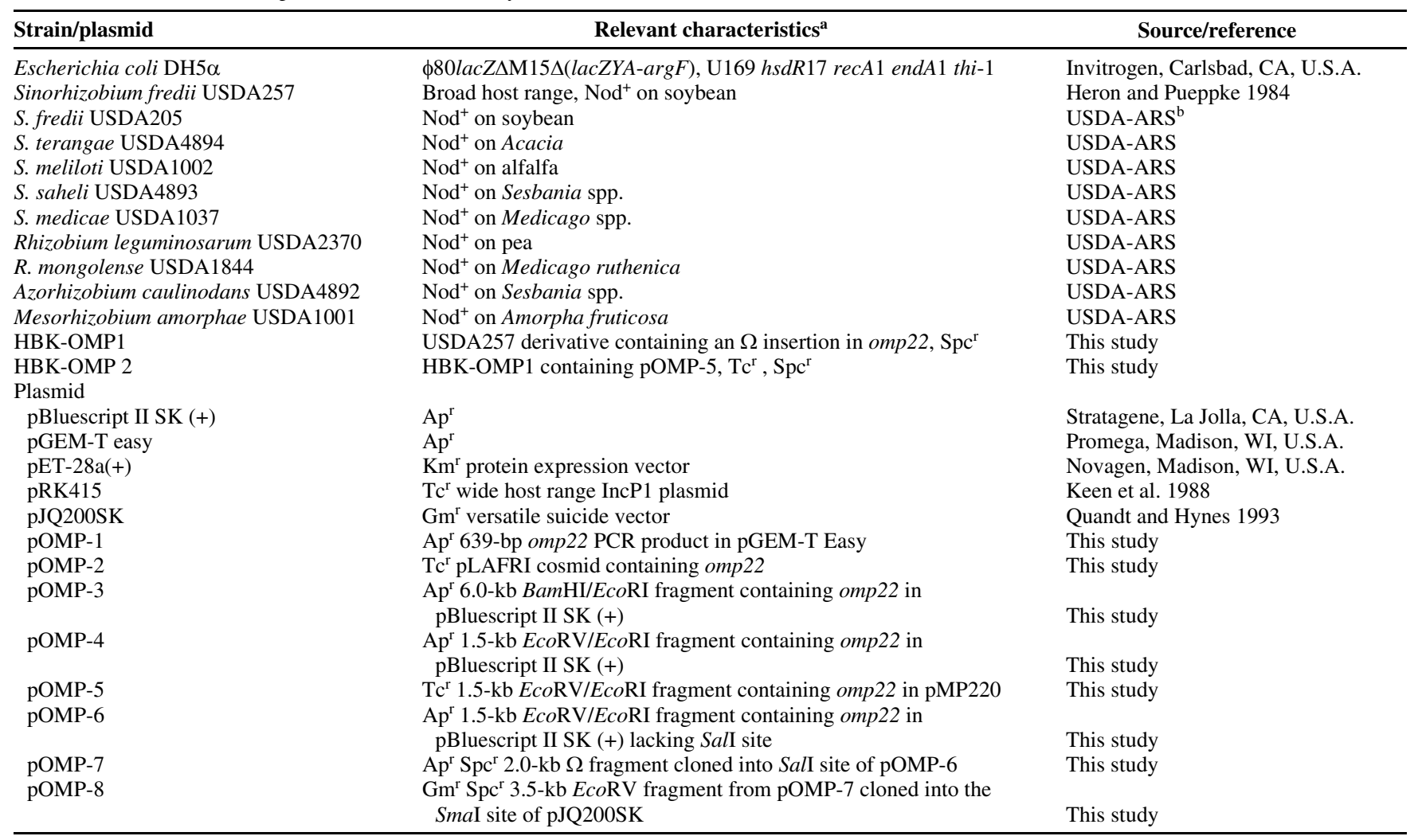

${ }^{\mathrm{a}} \mathrm{Spc}^{\mathrm{r}}, \mathrm{Tc}^{\mathrm{r}}, \mathrm{Ap}^{\mathrm{r}}, \mathrm{Km}^{\mathrm{r}}$, and $\mathrm{Gm}^{\mathrm{r}}$ indicate, respectively, spectinomycin, tetracycline, ampicillin, and gentamycin resistance.

${ }^{\mathrm{b}}$ USDA-ARS $=$ United States Department of Agriculture-Agricultural Research Service. 
restriction digestion, Southern hybridization, and other procedures relating to nucleic acids were carried out according to established procedures (Sambrook et al. 1989).

\section{Purification and analysis of flagella.}

Two-day-old USDA257 cultures grown in either calciumlimiting or calcium-sufficient media were subjected to centrifugation at $11,300 \times g$ for $30 \mathrm{~min}$ at $4^{\circ} \mathrm{C}$. Aliquots $(16 \mathrm{ml})$ of the resulting supernatants were centrifuged in a Beckman SW 50.1 rotor at $150,000 \times g$ for $90 \mathrm{~min}$. Pellets from this ultracentrifugation were resuspended in either $200 \mu \mathrm{l}$ of distilled water or SDS-sample buffer in preparation for transmission electron microscopy or SDS-PAGE, respectively.

\section{Electron microscopy.}

Transmission electron microscopy and cold field emission scanning electron microscopy were performed as described by Krishnan and associates (2003).

\section{Amino-terminal sequence analysis.}

A flagellar protein preparation from USDA257 grown in calcium-limiting medium was separated by SDS-PAGE (Laemmli 1970). Resolved proteins were electrophoretically transferred to a polyvinylidene fluoride (PVDF) membrane and were visualized by briefly staining with Coomassie brilliant blue. The PVDF membrane containing the 22-kDa protein was excised, destained using a solution of $50 \%$ methanol and $10 \%$ glacial acetic acid (vol/vol), and then, was rinsed in distilled water. Terminal amino acid sequence was analyzed on a Procise 494 protein sequencer (Perkin-Elmer/Applied Biosystems, Foster City, CA, U.S.A.) at the University of Nebraska Proteomics Protein Core Facility (Omaha, NB, U.S.A.).

\section{Cloning and nucleotide sequence analysis of USDA257 omp22.}

Two primers, 5'-ATGCGTACGCTCACCACCACCCTCATG$3^{\prime}$ and 5'-TCAGAACTTGACGCCCATACCGAGTTTG-3', corresponding to the amino and carboxy terminals of $S$. meliloti outer membrane protein (GenBank accession number AL591786), were selected to PCR amplify a 600-bp fragment, using USDA257 genomic DNA as the template. This fragment was cloned into pGEM T-Easy vector (Promega, Madison, WI, U.S.A.) to produce pOMP-1. Subsequently, the 600-bp fragment was labeled with ${ }^{32} \mathrm{P}$ and was used to screen a cosmid library of USDA257, resulting in the identification of four positive cosmid clones. Southern blot analysis revealed that all four cosmid clones contained a 6-kb BamHI/EcoRI fragment that hybridized to the radiolabeled probe. This fragment from one of the cosmid clones (pOMP-2) was purified and cloned into $\mathrm{pBS}$ vector, resulting in pOMP-3. Restriction map analysis revealed that a $1.5-\mathrm{kb} E c o \mathrm{RV} / E c o \mathrm{RI}$ fragment contained DNA sequences that hybridized to the ${ }^{32} \mathrm{P}$-labeled probe. This fragment was cloned into $\mathrm{pBS}$ and pMP220, resulting in pOMP-4 and pOMP-5, respectively. The DNA region bounded by HindIII and EcoRI sites of pOMP-4 was sequenced at the University of Missouri DNA Core Facility. This sequence was deposited in the GenBank database and appears under accession number AY254097.

\section{Construction of the USDA257 omp22 mutant.}

To create the USDA257 omp22 mutant, we identified a SalI site located near the $\mathrm{N}$ terminal of Omp22 and introduced an omega cassette (Prentki and Krisch 1984). We first eliminated the SalI site from the multiple cloning site of vector pBluesript II SK(+) and cloned a 1.5-kb EcoRV fragment from pOMP-4 into the corresponding site resulting in pOMP-6. A 2-kb omega fragment was cloned into the Sal I site of pOMP-6, generating
pOMP-7. The resulting mutated USDA257 omp22 region was excised as a $3.5-\mathrm{kb} E c o \mathrm{RV}$ fragment and was cloned into the SmaI site of the suicide plasmid pJQ2000 SK (Quandt and Hynes 1993) to produce pOMP-8. This construct was mobilized into USDA257 by triparental mating with helper plasmid pRK2013 (Figurski and Helinski 1979). Double recombinations were selected by plating rhizobia on minimal medium plates supplemented with $5 \%(\mathrm{wt} / \mathrm{vol})$ sucrose. Southern blot hybridization and PCR analysis were employed to confirm the mutants.

\section{Preparation of recombinant Omp22 and antibody production.}

The complete coding region of Omp22 was amplified by PCR, using pOMP1 DNA as the template. The forward primer (5'-aacccatatgATGCGTACGCTCACCACCACCCTC3') was designed to incorporate an $\mathrm{NdeI}$ site, and the reverse primer (5'-ggccctcgagGAACTTGACGCCCATACCGAGTTTG-3') included a Not I site to facilitate cloning. The PCR-amplified fragment was cloned into the NdeI/NotI sites of the $E$.coli expression vector pET28a(+) (Calbiochem-Novabiochem, San Diego, CA, U.S.A.), resulting in the addition of six histidine residues to the protein $\mathrm{C}$-terminus. Expression of the recombinant Omp22 was initiated by the addition of $1 \mathrm{mM}$ IPTG to $E$. coli ER2566 cultures containing the plasmid. Recombinant Omp22 was purified from bacterial lysate by nickel-affinity column chromatography (Qiagen, Valencia, CA, U.S.A.). Affinity-purified Omp22 was further purified by preparative gel electrophoresis and, subsequently, was used to generate polyclonal antibodies in a white New Zealand female rabbit at the University of Missouri. The procedure was done in accordance with protocols for ethical treatment of animals.

\section{Immunoblot analysis.}

Western blot analysis was carried out as described earlier (Burnett 1981). Polyclonal antibodies raised against $S$. meliloti wild-type flagella were provided by B. Scharf (University of Regensburg, Germany). Proteins immobilized on nitrocellulose membranes were incubated with antibodies that had been diluted 1:3,000 in TBS (10 mM Tris- $\mathrm{HCl}, \mathrm{pH} 7.5,500 \mathrm{mM}$ $\mathrm{NaCl}$ ) containing 5\% nonfat dry milk. Nonspecifically bound antibodies were removed by several washes in TBST (TBS containing $0.3 \%$ Tween 20). The membrane was then incubated with goat anti-rabbit IgG-horseradish peroxidase conjugate and immuno-reactive polypeptides were detected with an enhanced chemiluminescent substrate (Super Signal West Pico trial kit; Pierce Biotechnology, Rockford, IL. U.S.A.) according to the manufacturer's protocol.

\section{Immunocytochemical localization of Omp22.}

Calcium-deficient media $(10 \mathrm{ml})$ supporting USDA257 cells grown to late exponential phase were pelleted in a $30-\mathrm{ml}$ Corex tube. The pellet was resuspended in $200 \mu \mathrm{l}$ of $50 \mathrm{mM}$ cacodylate buffer, $\mathrm{pH} 7.0$, and was immediately mixed with $800 \mu \mathrm{l}$ of $2 \%$ molten Bacto agar. The solidified agar blocks were sliced into 3- to 4-mm cubes and were fixed in $2.5 \%$ glutaraldehyde in $50 \mathrm{mM}$ cacodylate buffer, $\mathrm{pH}$ 7.0. Blocks were postfixed with osmium tetroxide, dehydrated in a graded acetone series, infiltrated, and embedded in Spurr's resin as described (Krishnan 2002). Thin sections of USDA257 cells, collected on nickel grids, were incubated for $2 \mathrm{~h}$ with preimmune serum or USDA257 Omp22 antibodies that had been diluted 1:500 in TBS containing 1\% bovine serum albumin. Specifically bound antibodies were detected by incubating the grids in droplets containing $10 \mathrm{~nm}$ protein A-gold particles (Sigma Chemical Co., St. Louis). Following several rinses in TBST, the sections were stained with $1 \%$ aqueous uranyl acetate and 
were examined with a JEOL 1200 EX (Japan Electron Optics Laboratory Co., Ltd., Tokyo) transmission electron microscope at $80 \mathrm{kV}$.

\section{Nodulation tests.}

USDA257 and the omp22 mutant were pelleted from logphase cultures, were resuspended in sterile water to a titer of $10^{8}$ cells per milliliter. Roots of pregerminated 3-day-old Peking soybean plants were dipped in the bacterial suspension and were transferred to aseptically prepared plastic growth pouches. The plants were moved to an environmental chamber maintained at $28^{\circ} \mathrm{C}$, with light intensity and duration of 500 $\mu \mathrm{E} \mathrm{m} \mathrm{m}^{-2} \mathrm{~s}^{-1}$ for $12 \mathrm{~h}$ per day, respectively. Plants were watered as necessary with either distilled water or solutions of EGTA. Appearance of nodules was monitored beginning eight days after inoculation and on alternate days thereafter until day 20 . Nodulation experiments were repeated twice with 15 plants used for each treatment.

\section{ACKNOWLEDGMENTS}

We thank P. Beuselinck and J. Bennett for critically reviewing this manuscript. Names are necessary to report factually on available data; however, the United States Department of Agriculture (USDA) neither guarantees nor warrants the standard of product, and the use of the name by USDA implies no approval of the product to the exclusion of others that may be suitable.

\section{LITERATURE CITED}

Annapurna, K., and Krishnan, H. B. 2003. Molecular aspects of soybean cultivar-specific nodulation by Sinorhizobium fredii USDA257. Indian J. Exp. Biol. 41:1114-1123.

Balatti, P. A., Krishnan, H. B., and Pueppke, S. G. 1991. Calcium regulates growth of Rhizobium fredii and its ability to nodulate soybean cultivar Peking. Can. J. Microbiol. 37:542-548.

Blevins, D. G., Barnett, N. M., and Bottino, P. T. 1977. The effects of calcium and the ionophore A23187 on nodulation, nitrogen fixation and growth of soybeans. Physiol. Plant 45:235-238.

Burnett, W. N. 1981. Western blotting: Electrophoretic transfer of proteins from SDS-polyacrylamide gels to unmodified nitrocellulose and radiographic detection with antibody and radioiodinated protein-A. Anal. Biochem. 112:195-203.

Caetano-Anollés, G., Lagares, A., and Favelukes, G. 1989. Adsorption of Rhizobium meliloti to alfalfa roots: Dependence on divalent cations and pH. Plant Soil 117:67-74.

de Maagd, R. A., de Rijk, R., Mulders, I. H. M., and Lugtenberg, B. J. J. 1989a. Immunological chacterization of Rhizobium leguminosarum outer membrane antigens using polyclonal and monoclonal antibodies. J. Bacteriol. 171:1136-1142.

de Maagd, R. A., Wientjes, F. B., and Lugtenberg, B. J. J. 1989b. Evidence for divalent cation $\left(\mathrm{Ca}^{2+}\right)$-stabilized oligomeric proteins and covalently bound protein-peptidoglycan complexes in the outer membrane of Rhizobium leguminosarum. J. Bacteriol. 171:3989-3995.

de Maagd, R. A., Wijfjes, A. H. M., Spaink, H. P., Ruiz-Sainz, J. E., Wijffelman, C. A., Okker, R. J. H., and Lugtenberg, B. J. J. 1989c. nod $O$, a new nod gene of the Rhizobium leguminosarum biovar viciae sym plasmid pRL1J1, encodes a secreted protein. J. Bacteriol. 171:6764-6770.

de Maagd, R. A., Mulders, I. H. M., Canter Cremers, H. C. J., and Lugtenberg, B. J. J. 1992. Cloning, nucleotide sequencing, and expression in Escherichia coli of a Rhizobium leguminosarum gene encoding a symbiotically repressed outer membrane protein. J. Bacteriol. 174:214-222.

de Maagd, R. A., Yang, W.-C., Goosen-de Roo, L., Mulders, I. H. M., Roest, H. P. Spaink, H. P., Bisseling, T., and Lugtenberg, B. J. J. 1994. Down regulation of expression of the Rhizobium leguminosarum outer membrane protein gene ropA occurs abruptly in interzone II-III of pea nodules and can be uncoupled from nif gene activation. Mol. PlantMicrobe Intact. 7:276-281.

Economou, A., Hamilton, W. D. O., Johnston, A. W. B., and Downie, J. A. 1990. The Rhizobium nodulation gene nodO encodes a $\mathrm{Ca}^{2+}$-binding protein that is exported without $\mathrm{N}$-terminal cleavage and is homologous to haemolysis and related proteins. EMBO (Eur. Mol. Biol. Organ.) J. 9:349-354.
Figurski, D., and Helinski, D. R. 1979. Replication of an origin-containing derivative of plasmid $\mathrm{RK}_{2}$ dependent on a plasmid function provided in trans. Proc. Natl. Acad. Sci. U.S.A. 76:1648-1652.

Galán, J. E., and Colmer, A. 1999. Type III secretion machines: Bacterial devices for protein delivery into host cells. Science 284:1322-1328.

Götz, T. D., Limmer, K., Ober, K., and Schmitt, R. 1982. Motility and chemotaxis in two strains of Rhizobium with complex flagella. J. Gen. Microbiol. 128:789-798.

Graham, P. H. 1992. Stress tolerance in Rhizobium and Bradyrhizobium, and nodulation under adverse soil conditions. Can. J. Microbiol. 38:475-484.

He, S. Y. 1998. Type III protein secretion systems in plant and animal pathogenic bacteria. Ann. Rev. Phytopathol. 36:363-392.

He, S. Y., Nomura, K., and Whittam, T. S. 2004. Type III protein secretion mechanisms in mammalian and plant pathogens. Biochim. Biophys. Acta 1694:181-206.

Heron, D. S., and Pueppke, S. G. 1984. Mode of infection, nodulation specificity, and indigenous plasmids of 11 fast-growing Rhizobium japonicum strains. J. Bacteriol. 160:1061-1066.

Heron, D. S., Ersek, T., Krishnan, H. B., and Pueppke, S. G. 1989. Nodulation mutants of Rhizobium fredii USDA257. Mol. Plant-Microbe Interact. 2:4-10.

Humphrey, B. A., and Vincent, J. M. 1965. The effect of calcium nutrition on the production of diffusible antigens by Rhizobium trifolii. J. Gen. Microbiol. 41:109-118.

Jia, Y. H., Li, L. P., Hou, Q. M. and Pan, S. Q. 2002. An Agrobacterium gene involved in tumorgenesis encodes an outer membrane protein exposed on the bacterial cell surface. Gene 284:113-124.

Joys, T. M. 1988. The flagellar filament. Can. J. Microbiol. 34:452-458.

Keen, N. T., Tamaki, S., Kobayashi, G., and Trollinger, D. 1988. Improved broad-host-range plasmids for DNA cloning in gram-negative bacteria. Gene 70:190-197.

Keyser, H. H., Bohlool, B. B., Hu, T. S., and Weber, D. F. 1982. Fastgrowing rhizobia isolated from root nodules of soybean. Science 215:1631-1632.

Kovacs, L. G., Balatti, P. A., Krishnan, H. B., and Pueppke, S. G. 1995. Transcriptional organization and expression of nolXWBTUV, a locus that regulates cultivar-specific nodulation of soybean by Rhizobium fredii USDA257. Mol. Microbiol. 17:923-933.

Krishnan, H. B., and Pueppke, S. G. 1993a. Purification, partial characterization, and subcellular localization of a 38 kilodalton, calcium-regulated protein of Rhizobium fredii USDA208. Arch. Microbiol. 159:250256.

Krishnan, H. B. 2002. Nolx of Sinorhizobium fredii USDA257, a type IIIsecreted protein involved in host range determination, is localized in the infection threads of cowpea (Vigna unguiculata [L.] Wolp) and soybean (Glycine max [L.] Merr.) nodules. J. Bacteriol. 184:831-839.

Krishnan, H. B., and Pueppke, S. G. 1993b. Flavonoid inducers of nodulation genes stimulate Rhizobium fredii USDA257 to export proteins into the environment. Mol. Plant-Microbe Interact. 6:107-113.

Krishnan, H. B., Lorio, J., Kim, W. S., Jiang, G., Kim, K. Y., DeBoer, M., and Pueppke, S. G. 2003. Extracellular proteins involved in soybean cultivar-specific nodulation are associated with pilus-like surface appendages and exported by a type III protein secretion system in $\mathrm{Si}$ norhizobium fredii USDA257. Mol. Plant-Microbe Interact. 16:617-625.

Krupski, G., Götz, R., Ober, K., Pleier, E., and Schmitt, R. 1985. Structure of complex flagellar filaments in Rhizobium meliloti. J. Bacteriol. 162:361-366.

Laemmli, U. K. 1970. Cleavage of structural proteins during the assembly of the head of bacteriophage T4. Nature (London) 227:680-685.

Lie, T. A., and van Egeraat, A. W. S. M. 1988. Iron-ethylene diamine tetraacetic acid, a specific inhibitor for root-nodule formation in the legume-Rhizobium symbiosis. J. Plant Nutr. 11:1025-1031.

Lorio, J. C., Kim, W. S., and Krishnan, H. B. 2004. NopB, a soybean cultivar-specificity protein from Sinorhizobium fredii USDA257, is a type III secreted protein. Mol. Plant-Microbe Interact. 17:1259-1268.

Lowther, W. L., and Loneragan, J. F. 1968. Calcium and nodulation in subterranean clover (Trifolium subterraneum L.). Plant Physiol. 43:13621366.

Marie, C., Broughton, W. J., and Deakin, W. J. 2001. Rhizobium Type III secretion systems: Legume charmers or alarmers? Curr. Opin. Plant Biol. 4:336-342.

Marie, C., Deakin, W. J., Viprey, V., Kopciñska, J., Golinowski, W., Krishnan, H. B., Perret, X., and Broughton, W. J. 2003. Characterization of Nops, nodulation outer proteins, secreted via the type III secretion system of NGR234. Mol. Plant-Microbe Interact. 16:743-751.

Maruyama, M., Lodderstaedt, G., and Schmitt, R. 1978. Purification and biochemical properties of complex flagella isolated from Rhizobium lupini H13-3. Biochim. Biophys. Acta 535:110-124. 
Meinhardt, L. W., Krishnan, H. B., Balatti, P. A., and Pueppke, S. G. 1993. Molecular cloning and characterization of a sym plasmid locus that regulates cultivar-specific nodulation of soybean by Rhizobium fredii USAD257. Mol. Microbiol. 9:17-29.

Munns, D. N. 1970. Nodulation of Medicago sativa in solution culture. V. Calcium and $\mathrm{pH}$ requirement during infection. Plant Soil 32:90-102.

Prentki, P., and Krisch, H. M. 1984. In vitro insertional mutagenesis with a selectable DNA fragment. Gene 29:303-313.

Quandt, U., and Hynes, M. F. 1993. Versatile suicide vectors which allow direct selection for gene replacement in gram-negative bacteria. Gene 127:15-21.

Robinson, J. B., Tuovinen, O. H., and Bauer, W. D. 1992. Role of divalent cations in the subunit associations of complex flagella from Rhizobium meliloti. J. Bacteriol. 174:3896-3902.

Roest, H. P., Goosen-de Roo, L., Wijffelman, C. A., de Maagd, R. A., and Lugtenberg, B. J. J. 1995a. Outer membrane protein changes during bacteroid development are independent of nitrogen fixation and differ between indeterminate and determinate nodulating host plants of Rhizobium leguminosarum. Mol. Plant-Microbe Interact. 8:14-22.

Roest, H. P., Mulders, I. H. M., Wijffelman, C. A., and Lugtenberg, B. J. J 1995b. Isolation of ropB, a gene encoding a 22-kDa Rhizobium leguminosarum outer membrane protein. Mol. Plant-Microbe Interact. 8:576583

Sambrook, J., Fritsch, E. F., and Maniatis, T. 1989. Molecular Cloning: A Laboratory Manual, 2nd ed. Cold Spring Harbor Laboratory, Cold Spring Harbor, NY, U.S.A.

Schmitt, R., Raska, I., and Mayer, F. 1974. Plain and complex flagella of Pseudomonas rhodas: Analysis of fine structure and composition. J Bacteriol. 117:844-857.

Smit, G., Kijne, J. W., and Lugtenberg, B. J. J. 1987. Involvement of both cellulose fibrils and $\mathrm{Ca}^{2+}$-dependent adhesin in the attachment of
Rhizobium leguminosarum to pea root hair tips. J. Bacteriol. 169:42944301

Smit, G., Kijne, J. W., and Lugtenberg, B. J. J. 1989a. Roles of flagella, lipopolysaccharide, and a $\mathrm{Ca}^{2+}$-dependent cell surface protein in attachment of Rhizobium leguminosarum biovar viciae to pea root tips. J. Bacteriol. 171:569-572.

Smit, G., Logman, T. J., Boerrigter, M. E. T. I., Kijne, J. W., and Lugtenberg, B. J. J. 1989b. Purification and partial characterization of the Rhizobium leguminosarum bv. viciae $\mathrm{Ca}^{2+}$-dependent adhesin, which modifies the first step in attachment of cells of the family Rhizobiaceae to plant root hair tips. J. Bacteriol. 171:4054-4062.

Struyvé, M., Moons, M., and Tomassen, J. 1991. Carboxyterminal phenylalanine is essential for the correct assembly of a bacterial outer membrane protein. J. Mol. Biol. 218:141-148.

Udvardi, M. K., and Day, D. A. 1997. Metabolite transport across symbiotic membranes of legume nodules. Annu. Rev. Plant Physiol. Plant Mol. Biol. 48:493-523.

Vincent, J. M. 1962. Influence of calcium and magnesium on the growth of Rhizobium. J. Gen. Microbiol. 28:658-663.

Vincent, J. M. 1970. A manual for the practical study of root-nodule bacteria. Blackwell Scientific Publications, Oxford.

Vincent, J. M., and Humphrey, B. A. 1963. Partition of divalent cations between bacterial wall and cell contents. Nature (London) 199:149151.

Viprey, V., Greco, A. D., Golinowski, W., Broughton, W. J., and Perret, X. 1998. Symbiotic implications of type III protein secretion machinery in Rhizobium. Mol. Microbiol. 28:1381-1389.

Xi, C., Schoeters, E., Vanderleyden, J., and Michiels, J. 2000. Symbiosisspecific expression of Rhizobium etli casA encoding a secreted calmodulin-related protein. Proc. Natl. Acad. Sci. U.S.A. 97:1111411119. 